\title{
O MODELO ESTRUTURAL DO JOGO HERMENÊUTICO COMO FUNDAMENTO FILOSÓFICO DA EDUCAÇÃO
}

\author{
Structural model of the game hermeneutics \\ as philosophical foundations of Education
}

Marcos Alexandre Alves ${ }^{1}$

\begin{abstract}
Resumo: O objetivo deste trabalho é apresentar o modelo estrutural do jogo hermenêutico como fundamento da educação. Para tal, refletiremos sobre a dimensão metodológica da hermenêutica filosófica e sobre o modo e a forma de acontecer da educação à luz da experiência hermenêutica. Enquanto no método analítico, dialético sintético, a experiência é dissecada e, consequentemente, eliminada, no jogo hermenêutico a experiência é conservada e ampliada, constituindo-se como abertura sempre a novas possibilidades de pensar, conhecer, educar e agir. Neste sentido, procuraremos explicitar a seguinte questão: em que medida e como o jogo constitui elemento fundamental à educação sob a análise da hermenêutica filosófica? Especificamente, intencionamos esclarecer o papel do jogo para a hermenêutica filosófica de Gadamer e determinar a influência do caráter lúdico do jogo em sua contribuição à educação.
\end{abstract}

Palavras-chave: Hermenêutica. Jogo. Educação.

\begin{abstract}
The aim of this paper is to present the structural model of the game as a hermeneutic foundation of education. To do this we will reflect on the methodological dimension of philosophical hermeneutics and the method and form of education which happen through the experience of hermeneutics. While the analytical method, dialectical, synthetic experience is dissected and, therefore, eliminated from the game, hermeneutic experience is preserved and expanded, establishing itself as always open to new possibilities of thinking, knowing, educating and acting. In this sense, we aim to clarify the following question: to what extent and how fundamental is the game to education in this analysis of philosophical hermeneutics? Specifically, we intend to clarify the role of the game for Gadamer's philosophical hermeneutics and the influence of the playful character of the game in his contribution to education.
\end{abstract}

Keywords: Hermeneutics Game. Education.

\footnotetext{
${ }^{1}$ Licenciado em Filosofia, doutorando em Educação. Docente, Centro Universitário Franciscano. Santa Maria,
} RS, Brasil. >maralexalves@gmail.com>

Travessa Visconde de Uruguai, 25

Perpétuo Socorro - Santa Maria, RS

97.045-500 
Alves, M. A.

\section{Introdução}

Propomo-nos, neste trabalho, a apresentar a noção de jogo como fundamento da educação, segundo a hermenêutica filosófica. Na hermenêutica, o processo de conhecer, de pensar e de ensinar não é predeterminado por uma força causadora a priori, nem por uma teleologia que lhe seja externa. Mais importante que a produção de uma certeza, é o processo interativo, experiencial e dialógico. A totalidade filosófica e educativa espelha-se no acontecer hermenêutico como jogo. Contudo, o jogo não representa um círculo vicioso, pois o filosofar e o educar efetivam-se de modo relacional ao procurarem compreender a totalidade a partir da finitude, a qual carrega aquela ânsia inesgotável de buscar compreender o todo, isto é, o desejo natural de conhecer.

O jogo circular do filosofar e educar não é vicioso nem puramente formal, não pode ser totalmente subjetivo ou objetivo, porque o compreender ocorre enquanto um jogo entre a tradição e a interpretação. A compreensão de sentido, que conduz nossa compreensão de um texto, não é uma atividade da subjetividade, mas se determina a partir da comunidade, que nos amarra com a tradição, que é uma totalidade, por um lado, fechada e, por outro, aberta. A noção de jogo retrata, exemplarmente, as relações entre o pensamento sistêmico e a hermenêutica filosófica. Assim, como ambas partem e pretendem chegar à totalidade compreensiva do mundo, da vida, ambas também comungam de uma forma, de uma metodologia, coerente com tal projeto tematizado na noção de jogo enquanto modo de conhecer, de pensar, de ensinar e de agir universal.

Para levarmos a termo nosso objetivo, qual seja: apresentar o modelo estrutural de jogo, segundo a hermenêutica filosófica, como fundamento da educação, teremos de refletir sobre a dimensão metodológica da hermenêutica filosófica e, mais especificamente, sobre o modo e a forma de acontecer da educação à luz do jogo como experiência hermenêutica. Ora, enquanto, no método analítico, dialético sintético, a experiência é dissecada e, consequentemente, eliminada, no jogo hermenêutico, a experiência é conservada e ampliada, constituindose como abertura sempre a novas possibilidades de pensar, conhecer, educar e agir. Neste sentido, procuraremos explicitar a seguinte questão: em que medida e como o jogo se constitui como elemento fundamental à educação sob a análise da hermenêutica filosófica? Especificamente, intencionamos esclarecer o papel do jogo para a hermenêutica filosófica de Gadamer (2007) e determinar a influência do caráter lúdico do jogo dialógico e sua contribuição à educação. Fundamentalmente, nosso estudo consiste em uma abordagem teórico-conceitual, de caráter filosófico, cuja fundamentação encontra-se, basicamente, nas obras Verdade e Método II (2004), Verdade e Método I (2007) e Educar é educar-se (2000) de H. G. Gadamer.

\section{A acepção metafórica e o emprego da noção de jogo}

Os jogos suscitam múltiplas representações e constituem um dos modos pelo qual são definidas as noções e as atitudes de que a humanidade tem se utilizado desde a antiguidade. Para Huizinga (1971), o uso de metáforas - melhor que o sentido literal - é que nos permite chegar à essência dos fenômenos. O problema é que a metáfora, do ponto de vista literal, positivista, foi rechaçada da filosofia. Do ponto de vista iluminista, unívoco, ela não possui 
função cognitiva, mas apenas valor ornamental, confundido, em geral, com a função de distrair, e não de instruir. Contudo, Gadamer (2007) afirma que quanto mais a gente metaforiza, melhor se compreende, ou ainda mais: quanto mais nos distanciamos do original, tanto mais teremos chance de descobrir o originário.

O jogo, na filosofia, em geral, ainda é malvisto, e, por aludir ao lúdico, é relegado ao horizonte do não filosófico. Ele não pertence à circunscrição conceitual utilitário-pragmática nem faz parte do rol dos métodos clássicos da filosofia. Não rejeitá-lo como filosófico resulta de um erro de perspectiva ou menosprezo categorial. Como se trata de atividade não orientada teleologicamente em direção a um fim a atingir, conclui-se que não possui razão. Porém, o jogo consiste e aborda um porquê, sem para quê. Da mesma forma que a rosa floresce sem porquê, o jogo é sem porquê, joga-se por jogar. É precisamente em seu 'sem para que', que vai, entretanto, de par com um 'porquê', que deve ser tomado a sério (GADAMER, 2007).

A compreensão da dignidade e da seriedade do jogo, como filosóficas, dependerá da perspectiva que se tiver presente. Quem parte de uma perspectiva analítica, matemática, portanto, parcial da linguagem, não compreende o jogo como uma metáfora metodológicofilosófica. O jogo sendo uma 'metáfora viva' (RICOEUR, 2000), uma metodologia do conhecer e pensar foi utilizada por alguns filósofos ao longo da tradição do pensamento ocidental. Quem parte de uma compreensão de totalidade pode compreendê-lo como uma metáfora e um modo de pensar autenticamente filosófico. Deste modo, para se chegar ao âmago da essência do jogo, devemos confiar nas metáforas: pois a fenomenologia do jogo nos permite compreender melhor o fato de que as metáforas, longe de serem uma espécie de luxo da linguagem, jogam um papel central na articulação linguística do mundo (GADAMER, 2007). Portanto, na noção de jogo, como um todo ordenado e coerente, estão juntas, tensionalmente, a contingência e a liberdade, a razão forte e a razão fraca, a racionalidade apodítica e a racionalidade verossímil, o determinismo e o acaso. Por isto que, do ponto de vista filosófico-educacional, o ser humano não deveria ser apenas tomado como homo sapiens, homo faber ou homo lúpus, mas também e, sobretudo, como homo ludens (HUIZINDA, 1971).

Os jogos humanos podem ser classificados com base em quatro características fundamentais: de competição, de imitação, de acaso e de vertigem. Estas concepções de jogo mostram como se dá o decidir do vir-a-ser de uma civilização. No jogo acontece uma espécie de ajuste entre os diferentes elementos que compõem certa situação, verificando-se relações de interdependência e dependência estáveis. Nele acontecem, às vezes, situações em que se estabelecem duravelmente, até o final do jogo, quer a liderança incontestada de um dos times quer um marasmo generalizado, sem que a relação energética das forças que se defrontam imponha, mecanicamente, um ou outro desfecho. Acontece e emerge algo no jogo que não pode ser previsto nem explicitado a priori nem a partir de suas partes isoladas (GADAMER, 2007).

O jogo constitui-se sempre como processo e, por isto mesmo, é sempre temporal, pois algo novo e imprevisto pode emergir. Nele, o que resulta, a coisa mesma, não é produto final da aplicação de uma técnica sobre algo. O que emerge, ao longo do processo, possui certa autonomia, em seu conjunto, com relação ao ponto de partida e com relação ao que está envolvido no mesmo. O motor principal do jogo reside na própria interação entre elementos realmente distintos ou entre partes semidistintas, no seio do organismo vivo.

$\mathrm{Na}$ filosofia, o jogo foi empregado, entre outros, por Heidegger (1989a), Wittgenstein (1975) e Gadamer (2007). Heidegger (1989a) usou a noção de jogo para descrever a transcen- 
Alves, M. A.

dência própria ao ser-no-mundo do Dasein humano. Listou, para tanto, diferentes jogos e chamou a atenção para a plurivocidade da noção de jogo. Com o projeto de dar um fundamento existencial à noção de 'visão de mundo', Heidegger (1989a) retomou a definição kantiana de 'homem do mundo' como aquele cuja habilidade e jogo de cintura o qualificam para participar no grande 'jogo da vida'. Neste caso, o 'mundo' do qual se trata aqui é a cena onde se desenvolve o 'jogo do ser-um-com-o-outro dos homens em sua relação ao ente'. Esta definição não apreende, pois, o homem como 'membro do cosmos', mas, ao contrário, em suas 'relações históricas de sua existência'. Wittgenstein (1975), em sua análise acentuadamente pragmática dos jogos de linguagem, entrelaçou, conjuntamente, as noções de gramática e de forma de vida. Seu foco de interesse pelo jogo concentra-se na 'noção de regra' existente e acentuada, ao passo que, para Heidegger (1989a), é a noção de jogo mesmo, como transcendência, o que interessa.

O emprego que Gadamer (2007) fez do jogo evidencia o fato de que, à execução do jogo de palavras, todos os empregos referem-se a fenômenos naturais ou impessoais, e não a atividades humanas. Compreende-se, então, melhor que o mundo, que está em questão tem o primado sobre a atividade humana. Ou seja, o jogo não enfatiza a proeza ou a performace de um sujeito, que mostra do que ele é capaz, mas como a descoberta que o si (sol) se encontra tomado em um jogo no qual ele não é o iniciador nem o senhor. Neste sentido, a experiência hermenêutica desenvolvida por Gadamer se apresenta como o "poder" ou a "faculdade" paradoxal de nos deixarmos atingir e afetar por um sentido e uma verdade que nos precede por causa da companhia eterna do jogo onde, de agente, o sujeito se torna "participante", destinatário do sentido do qual ele mesmo não é o autor (senhor).

\section{O jogo como estrutura metodológica da hermenêutica filosófica}

A hermenêutica é conhecida apenas como um instrumento apropriado às ciências humanas. Em oposição ao método analítico, que esclarece e disseca o objeto, seria um método interpretativo, compreensivo, apropriado à interpretação das coisas humanas. Há, contudo, um certo grau de fundamento nisto, porém, para Grondin (1999), depois das obras Ser e Tempo de Heidegger (1989a; 1989b) e Verdade e Método de Gadamer (2004; 2007), não é mais possível reduzir a hermenêutica a uma doutrina ou receituário interpretativo, nem concebê-la como uma atividade que se contrapõe à ciência moderna.

Já, na perspectiva de Rohden (2002), para se compreender melhor o jogo como método filosófico desenvolvido por Gadamer (2007), é necessário ter presente algumas reflexões de Heidegger (1989a), acerca da desconstrução do método cartesiano. Para Heidegger (1989a), por um lado, o método não é, agora, mais apenas a ordenada sucessão dos diversos passos da reflexão, demonstração, exposição e sistematização de conhecimentos. Por outro lado, o pensador se afastou também do método especulativo-dialético de Hegel (2003), sobretudo porque a subjetividade constitui seu estatuto fundamental. Ante estes dois métodos, Heidegger (1989a) justificou que o método especulativo-hermenêutico é o único possível e necessário para um pensamento que articula sua nova tarefa apoiada na estrutura binária de velamento e desvelamento: a questão do ser. Assim, para Stein (2008) a hermenêutica, na perspectiva de reconduzir os conceitos petrificados ao seu sentido original, realizou uma destruição, ou seja, uma 
desconstrução da subjetividade moderna. Gadamer (2007) assume este modo de filosofar e, na esteira da crítica ao método científico moderno, procurou alargar a noção de método. No momento, restringimo-nos a mostrar, numa concepção mais ampla de hermenêutica, o jogo como modelo estrutural metodológico apropriado à filosofia, desenvolvido por Gadamer (2007), na primeira parte de Verdade e Método I.

Para Gadamer (2007), os métodos da ciência natural não captam tudo o que vale a pena saber, nem sequer o que mais vale a pena: os fins últimos, que devem orientar todo o domínio dos recursos da natureza e do homem. Diferentemente do método científico, com o filosófico, não se pretende chegar a um fim último e definitivo, que elimina a história, a experiência e a instigante atitude filosófica de querer sempre saber mais. Ainda, de acordo com Gadamer (2007), somente uma consciência científica exacerbada até a cegueira pode ignorar que o debate sobre os verdadeiros fins da sociedade humana, ou a pergunta pelo ser em pleno predomínio do fazer, ou a recordação de nossa origem histórica e de nosso futuro, dependem de um saber que não é científico.

Para Stein (1998), não é por acaso que Gadamer intitulou sua obra Verdade e Método. Não a intitulou Verdade ou método nem Verdade contra o método nem pretendeu suprimir o método científico por outro lado. A redução do método filosófico ao modelo matemático, na modernidade, exige de nós uma reflexão, a fim de recolocarmos o sentido e o modo próprio da filosofia. Neste sentido, pode-se inferir que Gadamer (2007) apresentou o jogo como fio condutor da explicação ontológica.

Quando falamos de jogo no contexto da experiência da arte não nos referimos ao comportamento, nem ao estado de ânimo daquele que cria ou daquele que desfruta do jogo e muito menos à liberdade de uma subjetividade que atua no jogo, mas ao modo de ser da própria obra de arte. [...] De certo, pode-se diferenciar do próprio jogo o comportamento do jogador, que, como tal, se integra com outros modos de comportamento da subjetividade. [...] A partir disso, podemos procurar determinar o conceito de jogo. O que é mero jogo não é sério. O jogar possui uma referência essencial própria para com o que é sério. [...] O jogar só cumpre a finalidade que lhe é própria quando aquele que joga entra no jogo. Não é a referência que, a partir do jogo, de dentro para fora, aponta para a seriedade; é só a seriedade que há no jogo que permite que o jogo seja inteiramente um jogo. Quem não leva a sério o jogo é um desmanchaprazeres. O modo de ser do jogo não permite que quem joga se comporte em relação ao jogo como se fosse um objeto. Aquele que joga sabe muito bem o que é o jogo e que o que está fazendo é "apenas um jogo", mas não sabe o que ele "sabe" nisso". (GADAMER, 2007, p. 154-155)

Rigorosamente falando, o jogo não é um método compreendido como a realização de um caminho para se chegar a um fim determinado previamente. O jogo é um caminho, ou seja, um modelo estrutural segundo o qual podemos mostrar e explicar, com determinados pressupostos, condições e exigências, como se dá e deve ocorrer o saber filosófico. Assim, para evitar mal-entendidos, considerá-lo-emos um modelo estrutural, com pressuposto e condições filosóficas, no intuito de explicarmos, em última análise, os traços filosóficos próprios 
Alves, M. A.

da hermenêutica, diferente e complementar dos métodos científicos, dialéticos, analítico, fenomenológico (ALMEIDA, 2000).

Por jogo compreendemos o lúdico, o cúltico, o dramático, o literário. Muito mais que um mero fazer de conta, o jogo possui uma dimensão fixa, objetiva, com regras próprias, tempo limitado, espaço demarcado, ocorrendo na mais absoluta seriedade - embora seja um jogo. Contudo, ele só acontece com propriedades subjetivas, tais como: liberdade, correr o risco, consciência de que apenas após ter jogado saber-se-á o resultado ou o processo experiencial. Ou seja, para Gadamer (2007, p. 160):

O próprio jogo é um risco para o jogador. Só se pode jogar com possibilidades sérias. Isso significa, evidentemente, que alguém se engaja ao ponto de permitir que elas o superem e se imponham. $\mathrm{O}$ atrativo que o jogo exerce sobre o jogador reside exatamente nesse risco. Desfrutamos assim de uma liberdade de decisão que está correndo riscos e está sendo inapelavelmente restringida.

Com a noção de jogo, podem-se conservar os principais ganhos da modernidade: a objetividade científica e a subjetividade, pois, só joga, em sentido autêntico, quem se propõe a jogar. O jogador distingue-se do jogo por seu comportamento subjetivo, por sua liberdade de criação ao jogar. No jogo, como comportamento lúdico, não desaparecem todas as referências finais ou regras, mas permanecem, por assim dizer, suspensas, pois quem joga sabe que o jogo não é mais que jogo e este só cumpre o objetivo que lhe é próprio quando o jogador se abandona totalmente no jogo. A relação que o jogador possui com o jogo é diferente da relação com outros objetos. Nesse sentido, não é possível mostrar o sentido do jogo independentemente do jogador e vice-versa, ou seja, não é possível objetificá-lo totalmente.

Conforme Gadamer (2007), a obra de arte não pode ser compreendida nem apenas em si mesma, nem enquanto projeção subjetiva de quem a contempla. O verdadeiro ser da Arte converte-se numa experiência que modifica ao que a experiencia. Este é um dos elementos essenciais do jogo enquanto possui essência própria, independente da determinação consciente e voluntária dos jogadores em oposição ao determinismo da subjetividade moderna.

Ora, segundo Gadamer (2007, p. 155), “o sujeito do jogo não são os jogadores. Ele simplesmente ganha representação através dos que jogam o jogo”. É por isso que não devemos compreender o jogo como um simples desempenho de uma atividade teleologicamente predeterminada, como ocorre com uma determinada concepção do método dialético hegeliano. O sujeito é o jogo em si mesmo, joga e é jogado nele mesmo, sendo necessário que haja, no jogo, um outro que jogue com ele e responda às suas iniciativas com suas contrainiciativas. "Para que haja jogo não é absolutamente indispensável que outro participe efetivamente do jogo, mas é preciso que ali sempre haja um outro elemento com o qual o jogador jogue e que, de si mesmo, responda com um contralance ao lance do jogador" (GADAMER, 2007, p. 159). O jogo apresenta uma tarefa particular ao que joga, em que este não pode abandonar-se, total e simplesmente, à sua liberdade ao jogar. O jogo não se constitui de um movimento linear, mas assemelha-se ao movimento antistrófico das tragédias gregas.

O jogo precisa ser compreendido como um processo medial, mais que um simples instrumento. No jogo, para Gadamer (2007, p. 156), “sempre está implícito o vaivém de um 
movimento que não se fixa em nenhum alvo, onde termine". O ser do jogo não está na consciência ou na conduta de quem joga, mas, pelo contrário, atrai este ao seu círculo e o enche de seu espírito. O jogador experimenta o jogo como uma realidade que o supera.

O movimento que é jogo não possui nenhum alvo em que termine, mas renova-se em constante repetição. O movimento de vaivém é obrigatoriamente tão central para a determinação da essência do jogo que chega a ser indiferente quem ou o que executa esse movimento. $\mathrm{O}$ movimento do jogo como tal também é desprovido de substrato. É o jogo que é jogado ou que se desenrola como jogo; não há um sujeito fixo que esteja jogando ali. O jogo é a realização do movimento como tal. (GADAMER, 2007, p. 156-157)

Diferentemente do método científico que, partindo de uma hipótese procura apenas confirmá-la, num movimento semelhante ao de Ulisses que retornou ao mesmo ponto donde saiu, a hermenêutica filosófica, mostrável pelo modelo estrutural do jogo, assemelha-se à atitude corajosa e aberta à realidade, que encontramos em Abraão. A representação dramática é um jogo com uma estrutura consistente. O drama, ainda que o que representa seja um mundo complementar fechado em si mesmo, está aberto ao espectador. Sem espectador ele não alcança seu pleno significado. Ou seja, em Gadamer (2007, p. 163), “o espectador apenas realiza o que é o jogo como tal".

Neste sentido, o jogo dramático não está desligado da contingência das condições de acesso por parte do espectador. Vale dizer, em Gadamer (2007, p. 164), “o jogo aparece como representação para o espectador, ou seja, como espetáculo”. O jogo não é uma simples representação nem implica apenas autorreconhecimento, mas construção que não resulta apenas da atividade subjetiva nem da passividade objetiva, mas da interpretação e imbricação dessas duas polaridades. Também a interpretação é uma recriação, porém esta não se guia por um ato criador precedente, senão pela figura da obra já criada, pois ela mesma existe enquanto experiência, independente da consciência daqueles que jogam, porém cada qual deve representar como nela encontra algum sentido. Construção no sentido de que a experiência do espectador em relação ao drama, ou ao texto, leva a uma experiência enquanto produto da relação que acontece quando se interpreta ou assiste a um drama. Assistir a um drama é algo mais que a simples copresença com algo que também está aí. Assistir quer dizer participar. O que está entre o falar e o ouvir - que são traços constitutivos do compreender - designa e significa deixar ouvir, sentir, ouvir no sentido de estar atento, o que explicita o aspecto passivo do conhecimento humano. A concepção de jogo, como estrutura epistemológica própria da experiência artística, acena para o sentido humano da indiferença-ativa ante a obra de arte.

Não há separação entre sujeito e objeto no jogo, como método para conhecer e saber. Segundo Palmer (1989), entre ambos, há uma relação de pertença mútua. Para compreendermos o conceito de pertença será conveniente que observemos a dialética peculiar, contida no ouvir. Nesta perspectiva, está o fato de que quem é interpelado tem de ouvir, queira ou não. Não pode apartar seus ouvidos, tal como se aparta a vista de outra coisa, olhando para determinada direção, enquanto nenhum dos demais sentidos participa diretamente na universalidade da experiência linguística do mundo, já que cada um deles abarca tão somente o seu campo 
Alves, M. A.

específico, o ouvir é um caminho rumo ao todo, porque está capacitado para escutar o logos. E, talvez, contra a tirania do olhar, devêssemos explorar o que está contido no ouvir como uma face da metodologia hermenêutica.

Essa estrutura da experiência hermenêutica é contrária, pois, ao procedimento da ciência, uma vez que tem seu fundamento próprio no acontecer da linguagem. A insuficiência do conceito de método moderno se deve ao fato de pretender constituir-se numa reflexão externa. Para Hegel (2003), o verdadeiro método seria o fazer da própria coisa, contudo, obviamente que a coisa não anda seu caminho nem segue seu curso sem que nós pensemos.

O educar, o conhecer e o saber, a partir do modelo estrutural do jogo, ficam em aberto, no sentido de que não se concluem em conceitos definitivos. É o que ocorre na experiência estética em que há um jogo (a arte em si mesma), um jogador (espectador ativo, admirador) e o jogo, que consiste na experiência de admiração de uma obra de arte. Percebe-se que, nessa relação tripolar, não bipolar, não há eliminação nem sobreposição de um dos polos sobre os demais. O saber se constitui como um jogo e representação. A concepção de jogo desenvolvida por Gadamer (2007) implica uma pertença do jogador ao jogo. A distância do espectador em relação à representação cênica não é arbitrária, mas essencial para a constituição da unidade de sentido do jogo. Neste sentido, para Gadamer (2007, p. 164):

Mesmo o espetáculo teatral continua sendo jogo, isto é, tem a estrutura do jogo, estrutura de ser um mundo fechado em si mesmo. Mas, por mais fechado em si mesmo que seja o mundo representado no espetáculo cúltico ou profano, está como que aberto para o lado do espectador. É só neste que ganha o seu inteiro significado. Como em todo jogo, os atores representam seus papéis, e assim o jogo torna-se representação, mas o próprio jogo é o conjunto de atores e espectadores. De fato, é aquele que não participa do jogo mas assiste quem faz a experiência mais autêntica e que percebe a "intenção" do jogo. Nele o jogo eleva-se à sua idealidade própria.

O saber filosófico facultado pelo modelo estrutural do jogo remete-nos à experiência socrática de filosofar. Daí, para Gadamer (1983), que a filosofia tem sua origem: ela não é Sofia, disposição de um saber sobre algo, mas aspiração para ele. E como tal é a mais alta possibilidade das pessoas. Ou, então, a filosofia não se coloca jamais como uma ciência pronta e acabada; ela não abandona seu velho nome e continua sendo somente um projeto sempre inacabado e incompleto, sempre só amor à sabedoria.

Tanto o espectador, o intérprete, bem como o drama, a obra e o filósofo, cada um tem seu próprio horizonte. Filosofar consiste em assumir o desafio de pôr em jogo o horizonte que cada um carrega consigo para que ocorra uma autêntica fusão de horizonte. Em outras palavras, a hermenêutica supõe, descobre e apresenta as condições de verdade que não estão na lógica da investigação, senão que a precedem. Neste sentido, a hermenêutica, ao estar às voltas com a explicação de pressupostos e dogmas conceituais, não se concebe como simples conciliadora da realidade. Muito antes, revela-se como crítica ao procurar mostrar-se como jogo.

O pressuposto da inter-relação e da alteridade manifesta-se na explicação e execução do modelo estrutural do jogo. Deste modo, é possível desmascarar a atitude de neutralidade 
científica como garantia de verdade e ampliar o cogito cartesiano que, a princípio, pretende jogar sozinho, contrariando a lei do jogo. A partir do jogo, a verdade não é resultante de uma simples aplicação de um método. A verdade à qual se chega aplicando um método é uma verdade lógica, abstrata, em tudo diferente da verdade como filha do tempo, em tudo diferente de uma concepção de verdade irredutível à certeza.

É por esta razão que ressaltamos que a atitude do jogador não deve ser compreendida como um comportamento da subjetividade, já que é, antes, o próprio jogo o que joga, na medida em que inclui em si os jogadores e se converte deste modo no verdadeiro subjectum do movimento lúdico. O filosofar, para Gadamer (2007), converte-se num jogo irredutível ao fazer de conta porque aquele que compreende já está sempre incluído num acontecimento, em virtude do qual se faz valer o que tem sentido; na medida em que compreendemos, estamos incluídos num acontecer da verdade e, quando queremos saber o que temos de crer, parecenos que chegamos demasiado tarde.

O equívoco da filosofia moderna foi, segundo Coreth (1973), ter fundamentado seu procedimento na metodologia das ciências naturais. Contudo, precisamos distinguir níveis de racionalidade. Não é possível pensar assuntos matemáticos, de modo provável. Talvez deveríamos falar em métodos filosóficos, como o analítico, o dialético, o indutivo, o fenomenológico, sem exclusivizar um caminho, um jogo. Como há diferentes jogos de linguagem, há diferentes jogos metodológicos, e a relação entre eles é como a relação entre parentes, afinal, a humanidade não pode ser encaixada num leito de Procrusto. Entretanto, o que permanece comum é o jogo com as exigências apresentadas anteriormente. Neste sentido, a hermenêutica, ao repensar o modo de filosofar, converte-se numa postura, num modo de ser, cuja experiência é mostrável pelo modelo estrutural do jogo. O jogo filosófico autêntico é aquele que nos arranca do nosso solipsismo e nos impulsiona a ver com mais sensibilidade e clareza, com mais amplidão e ostentação o real.

Gadamer (2007), com o seu método ensaístico, em oposição à possibilidade de se construir Sumas ou de se ocupar com disputas silogísticas, estéreis, com sua obra, quase toda escrita em forma de ensaios/artigos, se opôs à construção ou concepção de filosofia como um sistema absoluto. Porém, tem no centro de suas reflexões o ser humano, enquanto realidade concreta. Isto se explicitou, na forma de um saber, como um modo de viver que se joga com o mundo. Deste modo, seria temerário afirmar que ele defendeu um método contra outros, ou contra a verdade. Ampliou - e quisemos mostrar isto pelo modelo do jogo - tanto um quanto o outro. Outrossim, o que é a ética, como uma reflexão sobre a moral, senão uma aposta num jogo que deve ser jogado pela argumentação em torno da passagem do ser ao dever-ser? Passamos do tempo em que se impunham os princípios éticos pela autoridade. Neste sentido, para Rohden (2008, p. 87):

A Ética trata-se de um jogo, porque os sujeitos éticos devem estar envolvidos no mesmo para jogar e projetar o que deve ser assumido como bem de todos. O autoritarismo não joga, impõe. Os sistemas absolutos não jogam, induzem e deduzem. O dogmatismo não joga, crê. O ceticismo não joga, silencia. Enfim, quem pensa que sabe, se cala e somente quem ainda não sabe, propõe-se, sempre de novo, a jogar o jogo filosófico. 
Alves, M. A.

\section{Hermenêutica: diálogo - do jogo filosófico ao jogo educativo}

Nesta última parte da presente reflexão, procura-se estabelecer, a partir da noção de jogo, uma aproximação entre hermenêutica e educação (HERMANN, 2002). Trata-se, aqui, de apresentar o jogo como uma experiência hermenêutica enquanto modo de pensar, que expõe o modo reducionista de entender a educação a partir dos ditames da cientificização, em que o Outro se torna objetivado, para indicar que o processo educativo é uma experiência do próprio aluno, que se realiza pela linguagem. Quanto mais o processo pedagógico se aproxima dos parâmetros científicos, maior a pretensão de controle das circunstâncias em que ocorre tal processo. Dentro dessa estrutura deixam escapar a experiência dos atores envolvidos no processo, com seus inevitáveis preconceitos e danos, empobrecendo, assim, a experiência formativa. Na racionalidade científica, conforme Flickinger (1998), o processo pedagógico é interpretado como algo que se pode dominar, sendo, inclusive, traduzível em técnicas que promovam um ensino ativo. Na estrutura e abordagem do jogo na hermenêutica filosófica, a condução do processo pedagógico pela via científico-metodológica é um equívoco, porque desconsidera a pluralidade de concepções pedagógicas que expressam diferentes modos de socialização e de orientações valorativas em favor da crença de que só temos um caminho a seguir. Em contraposição a isto, busca na linguagem um horizonte, de relação educativa, não objetivável e que constitui um espaço interpretativo que não tem limites.

À luz do modelo estrutural do jogo hermenêutico, o processo pedagógico extrapola a relação sujeito-objeto, no sentido do sujeito que domina o objeto. Esta interpretação expõe a estreiteza das categorias prevalecentes nos sistemas de ensino (avaliação, procedimentos pedagógicos, metodologias). Tais determinações metodológicas costumam reduzir o espaço de experiência, em que aquele que aprende deve entregar-se à nova situação, aceitando o risco das incertezas. Por isto, em nome do jogo - abertura da experiência educativa, Gadamer (2000) afirma que "só através do diálogo é possível aprender" (p. 10) e, em seguida, completa: "educar é educar-se" (p. 11). Isto implica apreciar a posição do outro (aluno) como alguém que necessita ter suas capacidades e limites respeitados. Só neste espaço de jogo e de abertura dialógica pode se dar o convencimento necessário a respeito dos conteúdos da aprendizagem, e o aluno pode realizar sua própria experiência. A experiência educativa, enquanto jogo, o educar se constitui como educar-se, que, por sua vez, pressupõe reconhecer que o processo de educação é vulnerável e que se educar é uma exposição ao risco.

Para Gadamer (2000), o jogo educativo, enquanto reflexão hermenêutica, implica que, na compreensão de algo ou alguém, produz-se uma autocrítica. Deste modo, para que o conceito de emancipação não se torne abstração, é preciso pressupor que aquele que compreende não adota uma atitude de superioridade, mas sente a necessidade de submeter a exame sua suposta verdade, ou seja, necessita pôr em jogo seus próprios preconceitos. E isto só pode acontece, para Rohden (2002), no espaço do diálogo, gerando uma atitude de autocrítica. Portanto, jogo enquanto experiência educativa exige a exposição ao risco, às situações abertas e inesperadas, coincidindo com a impossibilidade de assegurar a tais práticas uma estrutura estável, que garanta o êxito da ação interventiva.

Uma abordagem hermenêutica da educação não pode deixar de reconhecer a fecundidade da experiência do estranhamento, pela constante necessidade de ruptura com a situação habitual, como exigência para penetrar no processo compreensivo. O sentido da educação não 
emerge de uma abstração, de uma subjetividade pura, nem encontra sua produtividade quando se entrega à rede de técnicas e procedimentos metodológicos, mas da entrega ao jogo da própria experiência educativa, aceitando o que ela tem de imprevisibilidade. Trata-se da lógica dos acontecimentos, que não é captável pela lógica dos conceitos. Deste modo, na educação, é importante a valorização da metáfora, pois ela amplia as possibilidades compreensivas, que, por sua vez, abrem espaço para a pluralidade contra o esmagamento do modelo único e seus perigos. Numa palavra, os jogos pedagógicos, a despeito do domínio buscado por diferentes técnicas, trazem consigo o movimento próprio da existência humana, que é a tensão entre iluminação e encobrimento.

Por conseguinte, na busca da aproximação entre hermenêutica e educação, parte-se, mais uma vez, do pensamento de Gadamer (2000), para quem o diálogo é espaço de compreensão mútua. O jogo e a experiência do conhecer, que acontecem no diálogo, implicam o deslocamento da possibilidade de se chegar ao conhecimento por uma ação da consciência do sujeito, para dar relevância à conversação. Assim, o aprender se realiza por meio do jogo do diálogo, de modo a tornar nítido o vínculo entre aprender, compreender e dialogar. Ou seja, o diálogo que busca a espontaneidade viva do perguntar e do responder, do dizer e deixar-se dizer, é modo próprio de a hermenêutica filosófica se estruturar. O diálogo se constitui, assim, na possibilidade de experimentar nossa singularidade e a experiência do outro com suas objeções ou sua aprovação. Ele só acontece quando deixa algo em nós. O diálogo não é a experiência de algo novo por si só, mas é algo outro que veio ao nosso encontro, que ainda não havíamos encontrado em nossa própria experiência do mundo. O diálogo possui uma força transformadora.

Gadamer trata do diálogo em várias partes de sua obra, mas o tematiza especificamente em Verdade e Método II (2004), no ensaio intitulado "incapacidade para o diálogo" (p. 242). Seu objetivo consiste em uma defesa do diálogo, contudo, aponta, paradoxalmente, para uma espécie de incapacidade para a conversação. Neste sentido, a partir de Gadamer (2004), pode-se questionar: até que ponto a arte do diálogo está desaparecendo no campo educativo? $\mathrm{Na}$ vida social e pedagógica de nossa época, não estamos assistindo a um processo crescente de monologização do comportamento humano? O monólogo não seria um fenômeno típico de uma educação que acredita excessivamente no processo técnico-científico e, por conseguinte, deixa de lado a dimensão ética? Que experiências específicas, no mundo moderno, fazem os nossos alunos se calarem? O que de fato está contribuindo para o que se tem chamado de incapacidade para o diálogo? E o que é o diálogo e qual a sua contribuição para uma autêntica educação?

Estas perguntas destinam-se a compreender o diálogo desde uma perspectiva mais abrangente, ou seja, a partir daquele diálogo que busca a espontaneidade viva do perguntar e do responder, do dizer e do deixar-se dizer. Deste modo, o diálogo é o modo próprio da hermenêutica filosófica se estruturar. Em outras palavras, segundo Hermann (2002, p. 91), “O diálogo se constitui assim na possibilidade de experimentar nossa singularidade e a experiência do outro com suas objeções ou sua aprovação. Ele só acontece quando deixa algo em nós".

Nesta perspectiva, Gadamer (2004) reconhece vários tipos de jogos de diálogo: pedagógico, negocial, terapêutico e poético - a) Diálogo pedagógico, aquele que acontece entre professor e aluno no processo de ensino. Na tradição, o diálogo sempre foi constitutivo da relação pedagógica, embora nem sempre os professores mantenham essa capacidade dialógi- 
Alves, M. A.

ca. Com frequência, quem ensina acredita que, quanto mais clareza, densidade e organização tiver o tema, melhor será o resultado obtido. Essa incapacidade para o diálogo se deve ao fato de o professor ser o transmissor autêntico da ciência. O aprisionamento da educação pelo modelo da cientificidade cria dificuldades para a abertura dialógica ao outro. A experiência educativa originária se alimenta da linguagem vivida no diálogo, que dá possibilidade para o homem constituir a si mesmo; b) Diálogo como negociação aparece na troca entre os interlocutores. O êxito deste diálogo ocorre quando surge um acordo, que pressupõe o saber ouvir, de modo a superar nossas próprias limitações. Os envolvidos no diálogo não são trocados como pessoas, mas na medida em que administram seus próprios interesses; c) Diálogo terapêutico acontece a partir de uma situação inicial em que a comunicação natural de alguém com os outros está impedida por ideias delirantes. A incapacidade para o diálogo decorre de estado patológico. Na situação terapêutica, o diálogo revela-se como um trabalho de esclarecimento, e não como uma simples aplicação do saber médico. A incapacidade para o diálogo aparece, também, quando o próprio envolvido não consegue se pôr em diálogo com o outro, no sentido de ouvi-lo ou ouvir mal. O diálogo autêntico exige a participação dos envolvidos, ou seja, pressupõe que o participante esteja aberto para mudar sua própria posição e entrar no jogo com o outro. A palavra que circula no diálogo desvela, questiona, configura identidades e demanda diferenças; d) Diálogo poético é uma força que desvela o ser e configura possibilidades. O diálogo não é um procedimento metodológico, mas se constitui na força do próprio educar, que é educar-se, no sentido de uma constante confrontação do sujeito consigo mesmo, com suas opiniões e crenças, pela condição interrogativa na qual vivemos. A peculiaridade da situação dialógica é que nenhum dos interlocutores tem uma posição superior à do outro. Ao contrário, os interlocutores têm de levar a sério a posição um do outro, e desse processo surge um conhecimento que, até então, não se encontrava disponível para nenhum dos envolvidos.

A despeito de uma diversidade de tipos de diálogos, por um lado, a incapacidade para a conversação aparece na forma daquela incapacidade que não se confessa a si mesma, onde o próprio envolvido no jogo dialógico não consegue colocar-se em diálogo com o outro. Essa incapacidade pode ser tanto subjetiva, resultante da incapacidade de ouvir, como objetiva, pela ausência de uma linguagem comum.

Por outro lado, a incapacidade para o diálogo vai se aprofundando na estrutura monológica de nossa civilização científica, que não nos permite mais prestar atenção ao sentido das palavras. O verdadeiro diálogo exige a participação de todos os envolvidos, em que estes têm a possibilidade de exporem as suas próprias posições culturais, científicas, filosofias, políticas, religiosas etc. Portanto, o diálogo autêntico pressupõe que os participantes estejam abertos para mudarem as suas próprias posições e entrarem no jogo com o outro. Isto porque, para Gadamer (2004), a palavra que circula no diálogo desvela, questiona, configura identidades e demarca diferenças.

Por conseguinte, Flickinger (1998), na esteira do pensamento gadameriano, defende que a educação, em seu sentido verdadeiro, é o lugar por excelência do jogo, do diálogo, o lugar por excelência da palavra e da reflexão, que ultrapassa a apropriação dos conhecimentos para nos conduzir à formação pessoal. Desde que podemos dizer a palavra, estamos em constante conversação com o mundo, instaurando a própria possibilidade de educar. A palavra que joga e circula no diálogo também é a palavra da pergunta: fazer a pergunta significa declarar a relatividade, a limitação de nosso conhecimento e reconhecer nossa finitude, mas, também, 
convite a si incessante. Deixar os que se educam dizer a palavra é radicalizar a ideia de que o homem possui linguagem. A abertura de horizontes que o diálogo possibilita permite à educação fazer valer a polissemia dos discursos e criar um espaço de compreensão mútua entre os envolvidos.

\section{Considerações finais}

Procuramos, nesta reflexão, explicitar dois eixos temáticos: em primeiro lugar, mostrar o ponto de tensão do jogo hermenêutico com o sistema filosófico marcado pelo cientificismo moderno de caráter eminentemente positivista, cuja pretensão foi atribuir um único caminho para se atingir a verdade. Neste sentido, a hermenêutica se insurge como uma contraposição a este modo monista científico-metodológico, enquanto espaço exclusivo de construção do conhecimento, trazendo o interpretar, o produzir sentido e a impossibilidade de separar o sujeito do mundo objetivado. Ou seja, a hermenêutica, como jogo filosófico, afasta-se do procedimento objetivador, peculiar à ciência moderna e, por conseguinte, recupera, para a subjetividade, a condição de pertencimento e familiaridade a uma cultura, que a constitui e predetermina todas as suas possibilidades de compreensão. Este modo de filosofar tematiza a compreensão da experiência humana no mundo, um mundo que, desde já, se oferece interpretado. Por isto, o seu problema central é mostrar que a verdade, enquanto experiência e vivência, é interpretação, é um ato histórico-cultural.

Em segundo lugar, analisamos em que medida a hermenêutica, como horizonte interpretativo, interfere e possibilita a compreensão do jogo educativo. No que toca à aproximação entre hermenêutica e educação, procuramos demonstrar quanto os resultados deste tipo de filosofia contribuem no campo educacional, sobretudo por viabilizarem uma autocompreensão, uma autocrítica da prática pedagógica, bem como gestar condições de possibilidade de se produzirem novas interpretações sobre o sentido da formação. A filosofia hermenêutica na educação resgata o seu verdadeiro caráter enquanto jogo dialógico, pois o ato de compreender pressupõe abertura ao Outro, ao mundo. Portanto, na educação como jogo dialógico, é o próprio sujeito que se educa com o Outro. Ou seja, o diálogo não é um mero procedimento metodológico, mas constitui-se como móvel do próprio educar, que é educar-se como um constante confronto da subjetividade consigo mesma, com suas vivências que pressupõem um mundo cultural anterior ao próprio sujeito. 
Alves, M. A.

\section{Referências}

ALMEIDA, C.; FLICKINGER. H.-G.; ROHDEN, L. Hermenêutica filosófica: nas trilhas de Hans-Georg Gadamer. Porto Alegre: EDIPUCRS, 2000.

CORETH, E. Questões fundamentais de hermenêutica. São Paulo: EPU, 1973.

FLICKINGER, H.-G. Para que filosofia da educação?: 11 teses. Perspectiva, Florianópolis, v. 16, n. 29, p. 15-22, 1998.

GADAMER, H.-G. La educación es educarse. Barcelona: Paidós, 2000.

A razão na época da ciência. Rio de Janeiro: Tempo Brasileiro, 1983.

. Verdade e método I: traços fundamentais de uma hermenêutica filosófica. 8. ed.

Petrópolis: Vozes, 2007.

Verdade e método II: complementos e índice. 2. ed. Petrópolis: Vozes, 2004.

GRONDIN, J. Introdução à hermenêutica filosófica. São Leopoldo: Editora Unisinos, 1999.

HEGEL, G. W. F. Fenomenologia do espírito. (v. único). 2. ed. Petropólis: Vozes, 2003.

HEIDEGGER, M. Ser e tempo I. 3. ed. Petrópolis: Vozes, 1989a.

Ser e tempo II. Petrópolis: Vozes, 1989b.

HERMANN, N. Hermenêutica e educação. Rio de Janeiro: DP\&A, 2002.

HUIZINGA, J. Homo ludens: o jogo como elemento da cultura. São Paulo: Perspectiva, 1971.

PALMER. R. Hermenêutica. Lisboa: Edições 70, 1989.

RICOUER, P. A metáfora viva. São Paulo: Loyola, 2000.

ROHDEN, L. Hermenêutica filosófica: entre a linguagem da experiência e a experiência da linguagem. São Leopoldo: Editora Unisinos, 2002.

STEIN, E. Aproximações sobre hermenêutica. 2. ed. Porto Alegre: EDIPUCRS, 2008.

. A questão do método em filosofia. Porto Alegre: Movimento, 1998.

WITTGENSTEIN, L. Investigações filosóficas. São Paulo: Abril Cultural, 1975.

Artigo recebido em novembro de 2010 e aceito em dezembro de 2010. 